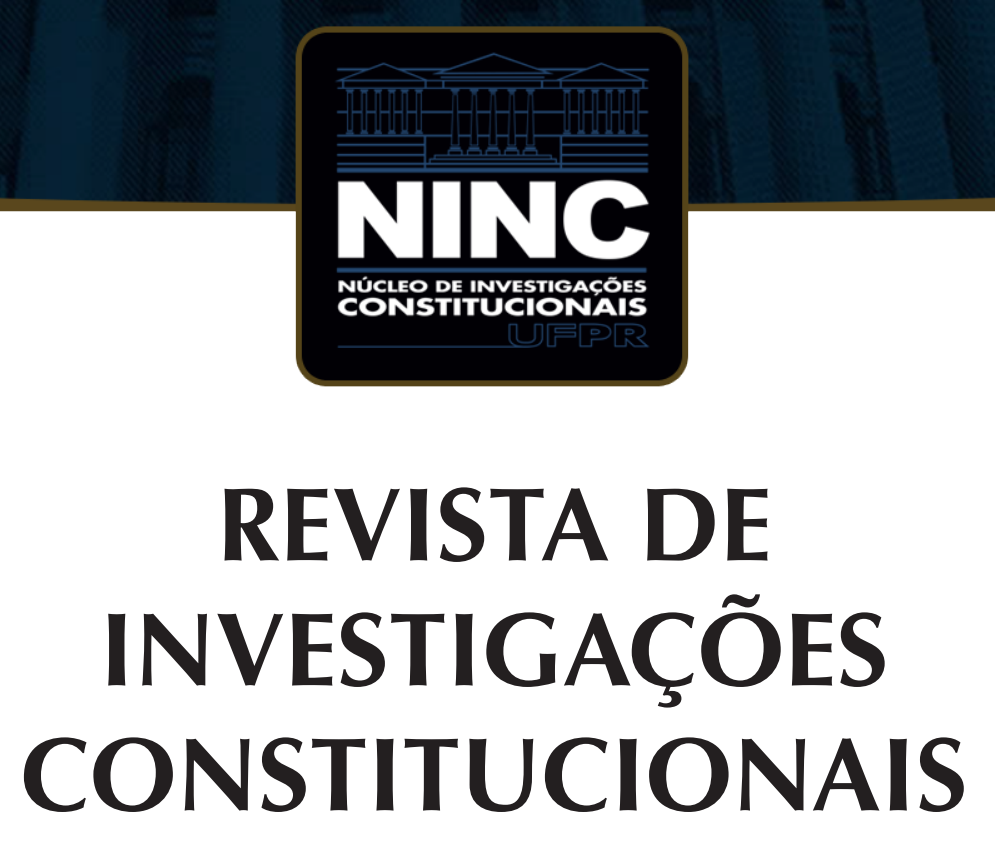

JOURNAL OF CONSTITUTIONAL RESEARCH

vol. 7 | n. 1 | janeiro/abril 2020 | ISSN 2359-5639 | Periodicidade quadrimestral Curitiba | Núcleo de Investigações Constitucionais da UFPR | www.ninc.com.br 


\title{
Concentrated judicial review in Brazil and Colombia: which (or whose) rights are protected?
}

\section{A concentração do controle judicial no Brasil e na Colombia: quais direitos (ou de quem) são protegidos?}

\author{
MARCUS FLÁVIO HORTA CALDEIRA I,
}

' Universidade de Brasília (Brasil) marcuscaldeira@unb.br https://orcid.org/0000-0003-2466-1519

Recebido/Received: 07.10 .2019 / October $7^{\text {th }}, 2019$ Aprovado/Approved: $17.10 .2020 /$ October $17^{\text {th }}, 2020$

\begin{abstract}
Over the last few decades, judicial power has expanded, especially in constitutional or supreme courts. Recently, scholars in comparative constitutional law have focused their attention on analyzing the causes and consequences of this expansion in different constitutional systems. There are still no studies that compare the role played by constitutional or supreme courts in the defense of individual and social rights, specifically with regard to the link between the protection of rights and the extent to which social actors are granted standing to assert constitutional claims. This paper intends to provide some thoughts on this issue. The text will analyze the relationship between the protection of rights and the extent to which plaintiffs are granted the right to file constitutional claims in Colombia and Brazil. We conclude that the comparison between Brazil and Colombia presents relevant insights into how the dimension of authority, specifically standing to access the main courts in each system, can make a large difference in the protection of social and individual rights.
\end{abstract}

\section{Resumo}

Nas últimas décadas, o Poder Judiciário tem se expandido, especialmente nos tribunais constitucionais ou supremas cortes. Recentemente, estudiosos do direito constitucional comparado têm focado sua atenção na análise das causas e consequências dessa expansão em diferentes sistemas constitucionais. Ainda não há estudos que comparem o papel desempenhado pelos tribunais constitucionais ou supremas cortes na defesa dos direitos individuais e sociais, especificamente no que se refere ao vínculo entre a proteção de direitos e o grau de legitimidade dos atores sociais para fazerem reivindicações constitucionais. Este artigo pretende fornecer algumas reflexões sobre este assunto. $O$ texto analisará a relação entre a proteção de direitos e a extensão em que os reclamantes têm o direito de entrar com ações constitucionais na Colômbia e no Brasil. Concluímos que a comparação entre Brasil e Colômbia apresenta percepções relevantes sobre como a dimensão da autoridade, especificamente a legitimidade para acessar os principais tribunais de cada Sistema pode fazer uma grande diferença na proteção dos direitos sociais e individuais.

Como citar esse artigo/How to cite this article: CALDEIRA, Marcus Flávio Horta. Concentrated judicial review in Brazil and Colombia: Which (or whose) rights are protected? Revista de Investigações Constitucionais, Curitiba, vol. 7, n. 1, p. 161-187, jan./abr. 2020. DOI: 10.5380/rinc.v7i1.69583.

" Professor (voluntário) na Faculdade de Direito da Universidade de Brasília (Brasília-DF, Brasil). Mestre em direito pelo IDP. Bacharel em direito pela UnB. E-mail: marcuscaldeira@unb.br. 
Keywords: protection of individual and social rights; Colombian Constitutional Court; Brazilian Federal Supreme Court; criteria of autonomy and authority; criteria for standing to access the courts.
Palavras-chave: proteção dos direitos individuais e sociais; Tribunal Constitucional da Colômbia; Supremo Tribunal Federal Brasileiro; critérios de autonomia e autoridade; critérios de legitimidade para aceder aos tribunais.

\section{CONTENTS}

1. Introduction; 2. The main types of constitutional review systems; 3. The mixed judicial review systems in Latin America and the models applied in Brazil and Colombia; 4. The criteria of autonomy and authority of constitutional and supreme courts and the instruments used by the Colombian Constitutional Court and the Brazilian Federal Supreme Court; 5. The effective protection of social and individual rights by the Brazilian Supreme Court and Colombian Constitutional Court and its relation to the standing to bring a constitutional lawsuit to these bodies; $\mathbf{6}$. Conclusion; 7. References.

\section{INTRODUCCIÓN}

Over the last few decades, scholars have noticed the expansion of judicial power and the consequent judicialization of politics. ${ }^{1}$ Some studies even consider that many constitutional systems are heading "towards juristocracy".2 As never before, countries are creating some form of judicial review or expanding the powers of the judicial branch (especially in constitutional or supreme courts) to pronounce what is (or is not) aligned with their Constitutions. The very definition of a constitutional question has been enlarged to embrace a wide variety of themes.

As the former proactive president of the Supreme Court of Israel once said, "nothing falls beyond the purview of judicial review; the world is filled with law, and anything and everything is justiciable". ${ }^{3}$

The declared goal of this expansion, as Brinks and Blass point out, is "creating more independence, more rights protection, more rule of law, more democracy, or all of these combined". ${ }^{4}$

Particularly in Latin America, since the 1970s, there have been constitutional, legal or jurisprudential reforms to insulate and strengthen the power of judges, making

\footnotetext{
BRINKS, Daniel.; BLASS, Abby. Rethinking Judicial Empowerment: The New Foundations of Constitutional Justice. International Journal of Constitutional Law, Oxford, v. 15, n. 2, p. 296-331, apr. 2017. p. 296.

2 HIRSCHL, Ran. 'Juristocracy' - Political, not Juridical. The Good Society, State College, vol. 13, n. 3, p. 6-11, nov. 2004; HIRSCHL, Ran. Towards Juristocracy: the origins and consequences of the new constitutionalism. Cambridge: Harvard University Press, 2007; HIRSCHL, Ran. The Judicialization of Mega-Politics and the Rise of Political Courts, Annual Review of Political Science, Palo Alto, v.11, p. 93.118, 2008.

3 HIRSCHL, Ran. The Judicialization of Mega-Politics and the Rise of Political Courts, Annual Review of Political Science, Palo Alto, v.11, p. 93.118, 2008. p. 95.

$4 \quad$ BRINKS, Daniel.; BLASS, Abby. Rethinking Judicial Empowerment: The New Foundations of Constitutional Justice. International Journal of Constitutional Law, Oxford, v. 15, n. 2, p. 296-331, apr. 2017. p. 297.
} 
the judicial power and, especially, the constitutional or supreme courts more independent and powerful than ever before. ${ }^{5}$

Recently, scholars in comparative constitutional law have focused their attention on analyzing the causes and consequences of the expansion of judicial power in different constitutional systems, ${ }^{6}$ which is yielding interesting data to better compare and understand the phenomenon. ${ }^{7}$ There are still very few studies that examine what types of rights are actually being protected by the constitutional and supreme courts in practice, particularly from a comparative perspective. Some good exceptions are the studies organized by Gretchen Helmke and Julio Ríos-Figueroa in "Courts in Latin America". ${ }^{8}$ However, as far as we know, there are no studies that compare the role played by constitutional or supreme courts in the defense of individual and social rights, specifically with regard to the link between the protection of rights and the extent to which social actors are granted standing to assert constitutional claims.

This paper intends to add some thoughts regarding this area by analyzing the relationship between the protection of rights and the extent to which plaintiffs are granted the right to file constitutional claims in Colombia and Brazil in the Colombian Constitutional Court (Corte Constitutional de Colombia) and to the Brazilian Supreme Court (Supremo Tribunal Federal), respectively.

The first section of this article we will briefly analyze the different main types of constitutional review systems. The second section, focusing in Latin America, will present the mixed system and characterize the Brazilian and the Colombian models. The third section will present the criteria of autonomy and authority for constitutional and supreme courts and the instruments used by the Colombian Constitutional Court and the Brazilian Federal Supreme Court. The fourth section will present data on the effective protection of social and individual rights by the Brazilian Supreme Court and Colombian Constitutional Court and on the relationship between the standing to bring constitutional lawsuits to constitutional and supreme courts and the protection of rights and how this relationship is seen in Colombia and Brazil.

\footnotetext{
BRINKS, Daniel.; BLASS, Abby. Rethinking Judicial Empowerment: The New Foundations of Constitutional Justice. International Journal of Constitutional Law, Oxford, v. 15, n. 2, p. 296-331, apr. 2017. p. 297.

6 HIRSCHL, Ran. 'Juristocracy' - Political, not Juridical. The Good Society, State College, vol. 13, n. 3, p. 6-11, nov. 2004; HIRSCHL, Ran. Towards Juristocracy: the origins and consequences of the new constitutionalism. Cambridge: Harvard University Press, 2007; HIRSCHL, Ran. The Judicialization of Mega-Politics and the Rise of Political Courts, Annual Review of Political Science, Palo Alto, v.11, p. 93.118, 2008.

7 GINSBURG, Tom; VERSTEEG, Mila. Why do countries adopt constitutional review? Journal of Law, Economics and Organization, Oxford, v. 30, n. 3, p. 587, 2014.

8 HELMKE, Gretchen; RIOS-FIGUEROA, Julio. Courts in Latin America. Cambridge: Cambridge University Press, 2011.
} 


\section{THE MAIN TYPES OF CONSTITUTIONAL REVIEW SYSTEMS}

Judicial review or constitutional review, which can be defined as "the formal power of a local court or a court-like body to set aside or strike legislation for incompatibility with the national constitution", which once was "an American peculiarity", as described by Alexis de Tocqueville, ${ }^{10}$ has spread throughout the globe. According to Ginsburg and Versteeg, ${ }_{11}^{11} 83 \%$ of the world's constitutions now include (explicitly or implicitly) some form of constitutional review.

The first system of constitutional review or judicial review was created in the United States of America and became famous after Marbury v. Madison, in 1803, when the Supreme Court of the US for the first time explicitly ruled that a federal law that is not in accordance with the constitution should be considered null and void. ${ }^{12}$

Although the US Constitution is not explicit about the power of federal courts to strike down statutes that are incompatible with it, many scholars ${ }^{13}$ believe that the founding fathers assumed that this role would be within the judicial power. Hamilton dedicated much of Federalist 78 to expressing the ideas that were put in practice by Marshall and the US Supreme Court in Marbury v. Madison. ${ }^{14}$

9 GINSBURG, Tom; VERSTEEG, Mila. Why do countries adopt constitutional review? Journal of Law, Economics and Organization, Oxford, v. 30, n. 3, p. 587, 2014. p. 4.

10 TOCQUEVILLE, Alexis de. Democracy in America. Tradução de R. D. Heffner. New York: New American Library, 2001. p. 72.

11 GINSBURG, Tom; VERSTEEG, Mila. Why do countries adopt constitutional review? Journal of Law, Economics and Organization, Oxford, v. 30, n. 3, p. 587, 2014. p. 4.

12 NOWAK, John. E.; ROTUNDA, Ronald D. Constitutional law. 4. ed. St. Paul: West Publishing Co., 1991, p. 1-20; 22-114.

13 SNOWISS, Sylvia. Judicial review and the law of the Constitution. New Haven: Yale University Press, 1990; TREANOR, William. Judicial Review before Marbury. Stanford Law Review, Stanford, v. 58, n. 2, p. 455-562, 2005; GINSBURG, Tom; VERSTEEG, Mila. Why do countries adopt constitutional review? Journal of Law, Economics and Organization, Oxford, v. 30, n. 3, p. 587, 2014.

14 From the decision in Marbury v. Madison, we point out the main reasons for judicial review: "It is, emphatically, the province and duty of the judicial department, to say what the law is. Those who apply the rule to particular cases, must of necessity expound and interpret that rule. If two laws conflict with each other, the courts must decide on the operation of each. So, if the law be in opposition to the constitution; if both the law and the constitution apply to a particular case, so that the court must either decide that case, conformable to the law, disregarding the constitution; or conformable to the constitution, disregarding the law; the court must determine which of these conflicting rules governs the case: this is of the very essence of judicial duty. If then, the courts are to regard the constitution, and the constitution is superior to any ordinary act of the legislature, the constitution, and not such ordinary act, must govern the case to which they both apply. Those, then, who controvert the principle, that the constitution is to be considered, in court, as a Paramount law, are reduced to the necessity of maintaining that courts must close their eyes on the constitution, and see only the law. This doctrine would subvert the very foundation of all written constitutions." (UNITED STATES. United States Supreme Court. Marbury v. Madison. Justia.com: US Supreme Court Center. 19 p. Disponível em: < http://supreme.justia.com/cases/federal/us/5/137/case.html>. Acesso em: 18 set. 2013. p. 17) 
The American system of judicial review is known to be decentralized, concrete and with inter partes and ex tunc effects. ${ }^{15}$ Therefore, all judges and courts can declare a law unconstitutional (decentralized model); this declaration must occur in the judgment of a case or controversy (concrete review), and the ruling will affect only the parts (inter partes effect) with retroactive effects, which convey the idea of the invalidity of the law since its creation (ex tunc effects). ${ }^{16}$

Over the course of the development of the American system, some of its traditional characteristics have been altered or softened. Stare decisis, typical of common law systems, which states that judges should observe the rulings of higher courts, directly affects the inter partes effect and even the decentralization of the system. As judges and courts should observe the decisions of higher courts, the rulings of higher courts, especially those of the US Supreme Court affect the decisions of all judges and tribunals all over the country. Therefore, the decisions of the US Supreme Court affect all litigants, not only the parties of the particular case. The role played by this court is decisive in terms of pronouncing the last word on constitutional (and legal) interpretation, which does not change the power that all judges have to use judicial review but instills far greater importance in the rulings of the US Supreme Court as the center of the most binding and final decisions in the country. ${ }^{17}$

Over the course of its development, American judicial review has started to admit nonretroactive effects ${ }^{18}$ and, as pointed out by Sweet and Shapiro (2006), ${ }^{19}$ has begun to exercise some kind of "abstract review of legislation". ${ }^{20}$ While the American

15 Based on the classification created by Mauro Cappelletti (CAPPELLETTI, Mauro. O controle judicial de constitucionalidade das leis no direito comparado. Tradução de Aroldo Plínio Gonçalves. 2. ed. reimpressão. Porto Alegre: Sergio Antonio Fabris, 1999).

16 CANOTILHO, José Joaquim Gomes. Direito constitucional e teoria da Constituição. 7 ed. Lisboa: Almedina, 2003. p. 64-65.

17 SEGADO, Francisco Fernandez. La obsolescencia de la bipolaridade tradicional (modelo Americano - modelo europeo-kelseniano) de los sistemas de justicia constitucional. Direito Público, Brasília, ano 1, n. 2, p. 55-82, out./dez. 2003.

18 According to Laurence Tribe: "First, the decision to be applied nonretroactively must establish a new principal of law, either by overruling past precedent on which litigants may have relied, or by deciding an issue of first impression whose resolution was not clearly foreshadowed. Second, ... we must ... weight the merits and demerits in each case by looking to de prior history of the rule in question, its purpose and effect, and whether retrospective operation will further or retard its operation. Finally, we [must] weig[h] the inequity imposed by retrospective application, for where a decision of this Court could produce substantial inequitable results if applied retroactively, there is ample basis in our cases for avoiding the injustice or hardship by a holding of nonretroactivity" (TRIBE, Laurence H. American constitutional law. 3. ed. New York: Foundation Press, v. 1, p. 207-285; 302-385, 2000. p. 219). Good examples of nonretroactive effects cases are Linkletter v. Walker and Chevron Oil Co. v. Huson (p. 218-219).

19 SWEET, Alec Stone; SHAPIRO, Martin. Abstract and concrete review in the United States. In: SWEET, Alec Stone; SHAPIRO, Martin. On Law, politics, and judicialization. Oxford: Oxford Scholarship Online. 2006.

20 Sweeet and Shapiro make the point of "abstract" judicial review in the U.S., by analyzing how the Courts behave in cases of "preliminar injunctions and declaratory judgments" and when it applies the criteria of "facial overbreadth and vagueness" (SWEET, Alec Stone; SHAPIRO, Martin. Abstract and concrete review in the United States. In: SWEET, Alec Stone; SHAPIRO, Martin. On Law, politics, and judicialization. Oxford: Oxford Scholarship Online. 2006). 
system does not have a special "constitutional claim" proceeding, the writ of certiorari is currently the main legal instrument through which to access the US Supreme Court. ${ }^{21}$ In contrast, with the "American" model, there is another system - called the "European" or "Austrian" system of judicial review - in which a specialized constitutional court has constitutional review power, while the rest of the judiciary cannot void legislation. Due to this characteristic, this system is also named the "centralized" model because judicial review is centralized in one organ. ${ }^{22}$

The centralized model, or "European" model, was created by Hans Kelsen and applied in the Austrian Constitution of 1920 (Oktoberverfassung), which conceived of the first constitutional court - the Austrian Verfassungsgerichstshof. The early Austrian system is described as centralized, abstract and with erga omnes and ex nunc or prospective effects, ${ }^{23}$ which is the exact opposite of the American model in its early development.

In the original Austrian model, constitutional questions could only be addressed by the federal government or by the government of the "Länder" - equivalent to states in a federal system - through a specific action and would be analyzed, not in the context of a case or controversy but as an "abstract" question of constitutionality. ${ }^{24}$ The court could void a law when it was considered unconstitutional, which affected all branches and organs in the federation and all the citizens (erga omnes effects), but the effects could be postponed to the future - six months ${ }^{25}$ after the decision. ${ }^{26}$

Due to the great limitations of the early model, in 1929, Austrian centralized constitutional review was expanded through the Verfassungsnovelle ${ }^{27}$ to create a "concrete" review system, in addition to the "abstract" review, through which constitutional questions could arrive at the Constitutional Court from the higher courts in the Austrian

\footnotetext{
21 REHNQUIST, William. H. The Supreme Court. New York: Vintage Books, 2002, p. 232.

22 KELSEN, Hans. Jurisdição constitucional. São Paulo: Martins Fontes, 2007; CAPPELLETTI, Mauro. O controle judicial de constitucionalidade das leis no direito comparado. Tradução de Aroldo Plínio Gonçalves. 2. ed. reimpressão. Porto Alegre: Sergio Antonio Fabris, 1999.

${ }^{23}$ ERMACORA, Felix. Österreichs Bundesverfassung und Hans Kelsen. In: MERKL, Adolf; VERDROß, Alfred; MARCIC, René; WALTER, Robert (Eds.). Festschrift Für Hans Kelsen Zum 90. Geburtstage. Wien: Verlag Franz Deuticke, 1971; KELSEN, Hans. Jurisdição constitucional. São Paulo: Martins Fontes, 2007; CAPPELLETTI, Mauro. $\mathbf{O}$ controle judicial de constitucionalidade das leis no direito comparado. Tradução de Aroldo Plínio Gonçalves. 2. ed. reimpressão. Porto Alegre: Sergio Antonio Fabris, 1999.

24 It is interesting to note that, according to Ginsburg and Versteeg (GINSBURG, Tom; VERSTEEG, Mila. Why do countries adopt constitutional review? Journal of Law, Economics and Organization, Oxford, v. 30, n. 3, p. 587, 2014. p. 5), the Austrian Constitutional Court was designed as an "explicitly political body" to "adjudicate constitutional disputes (chiefly those involving Austrian federalism)".

25 Six months in the early model (1920). Then, after 1929, there were great changes to the centralized model, which enlarged this period to up to a year.

26 KELSEN, Hans. Jurisdição constitucional. São Paulo: Martins Fontes, 2007.

27 A constitutional reform in Austria to enhance the centralized judicial review.
} 
judicial system - e.g., the Administrative Supreme Court (Verwaltungsgerichtshof) and the Austrian Supreme Court (Obstergerichtshof). ${ }^{28}$

The centralized system was adopted by a great number of countries, starting with Czechoslovakia (Const. art. 54.13 (1920)), Liechtenstein (Const. art. 104 (1921)), Iraq (Const. art. 83 (1925) and then by countries such as and Italy (1947) and Germany (1949)..$^{29}$ Ultimately, the system was adopted into the Basic Law of postwar Germany, which experimented with remarkable developments, especially the constitutional complaint (Verfassungsbeschwerd), an instrument that allows individuals to directly address constitutional questions to the court ${ }^{30} .{ }^{31}$ However, the German constitutional tradition was more closely connected to the ex tunc effects approach - which was a large difference from the Austrian model, which engaged in ex nunc (or prospective) effects $^{32}$; German jurisdiction, in some cases, evolved to accept nonretroactive effects in its decisions. ${ }^{33}$

Later, "Kelsenian" type constitutional courts were adopted in many European countries such as Portugal (1976), Spain (1978) and the former Soviet bloc after the cold war..$^{34}$

In addition to the "American" and the "European" (or "Austrian") models of constitutional review there is another centralized model associated with the 1958

28 ERMACORA, Felix. Österreichs Bundesverfassung und Hans Kelsen. In: MERKL, Adolf; VERDROß, Alfred; MARCIC, René; WALTER, Robert (Eds.). Festschrift Für Hans Kelsen Zum 90. Geburtstage. Wien: Verlag Franz Deuticke, 1971; KELSEN, Hans. Jurisdição constitucional. São Paulo: Martins Fontes, 2007; CAPPELLETTI, Mauro. $\mathbf{O}$ controle judicial de constitucionalidade das leis no direito comparado. Tradução de Aroldo Plínio Gonçalves. 2. ed. reimpressão. Porto Alegre: Sergio Antonio Fabris, 1999.

29 GINSBURG, Tom; VERSTEEG, Mila. Why do countries adopt constitutional review? Journal of Law, Economics and Organization, Oxford, v. 30, n. 3, p. 587, 2014. p. 6.

30 In addition to the constitutional complaint (Verfassungsbeschwerd), which corresponds to the largest number of cases, the German system includes "abstract" and "concrete" reviews as parts of the Federal Constitutional Court's (Bundesverfassungsgericht) jurisdiction. (SWEET, Alec Stone; SHAPIRO, Martin. Abstract and concrete review in the United States. In: SWEET, Alec Stone; SHAPIRO, Martin. On Law, politics, and judicialization. Oxford: Oxford Scholarship Online. 2006, p. 24).

31 PIEROTH, Bodo; SCHLINK, Bernhard. Direitos fundamentais. Tradução de António Francisco de Sousa e António Franco. São Paulo: Saraiva, 2012.

32 There was a big debate between Heckmann (HECKMANN, Dirk. Geltungskraft und Geltungsverlust von Rechtsnormen. Tübingen: Mohr Siebeck, 1997) and Ipsen (IPSEN, Jörn. Rechtsfolgen der Verfassungswidrigkeit von Norm und Einzelakt. Baden-Baden: Nomos Verlagsgesellschaft, 1980) on German constitutional law on ex nunc or ex tunc effects by the Constitutional Court case law. While HECKMANN defended ex nunc or prospective effects with arguments similar to the ones used by Kelsen, IPSEN, based on the German tradition, favored ex tunc effects. The traditional view has prevailed in the Bundesverfassungsgericht case law, but it has started to adopt prospective effects in some cases, according to $\S 79$ of the Constitutional Court Act (BVerfG -Bundesverfassungsgerichtsgesetz).

33 HEUN, Werner. Normenkontrolle. In: BAND, Erster. Festschrift 50 Jahre Bundesverfassungsgerich. Herausgegeben von Peter Badura und Horst Dreier: Verfassungsgerichtsbarkeit, Verfassungsprozeß. Tübigen: Mohr Siebeck, 2001. p. 633.

34 GINSBURG, Tom; VERSTEEG, Mila. Why do countries adopt constitutional review? Journal of Law, Economics and Organization, Oxford, v. 30, n. 3, p. 587, 2014, p. 6. 
Constitution of France; this model was transported to many former French colonies that gained independence. ${ }^{35}$ The French Conseil Constitutionnel was a specialized court that was known to exercise an "a priori" judicial review, which can be understood as a preventive constitutional review because it was designed to hear challenges to legislation from a limited number of governmental actors before legislation was promulgated. ${ }^{36}$ Constitutional amendments in 2008 transformed the French system to include postpromulgation review, making it much more similar to the German model. ${ }^{37}$

\section{THE MIXED JUDICIAL REVIEW SYSTEMS IN LATIN AMERICA AND THE MODELS APPLIED IN BRAZIL AND COLOMBIA}

Inspired by the American experience, many countries in Latin America created constitutions, such as Brazil (Imperial Constitution of 1824), Mexico (1824) and Gran Colombia $^{38}$ (1821, also called Cúcuta Constitution), etc. It was no surprise that the first model of judicial review adopted in certain countries in the region was the American model. ${ }^{39}$

After the emergence of the European model in 1920, some constitutions in Latin America started to practice "abstract" review in addition to the concrete review that continued to be used. ${ }^{40}$ There were countries that created specialized constitutional courts, such as Colombia. Others created special bodies inside their supreme courts to function as a "constitutional court", such as "Sala Cuarta" in Costa Rica. Others countries enlarged the jurisdiction of their supreme court to include the exercise of "abstract" review, which occurs in the Brazilian Supremo Tribunal Federal. ${ }^{41}$

35 FAVOREU, Louis. Constitutional courts. Baton Rouge: Center of Civil Law Studies - LSU Law Center, 2001. Disponível em: <http://books.google.com.br/books?id=CVxQAQAAIAAJ\&q=louis+favoreu+2001\&dq=louis +favoreu+2001\&hl=en\&sa=X\&ei=tUnlU9OVBo7ksATql4CoBQ\&ved=0CBsQ6AEwAA >. Acesso em: 3 abr. 2014; CANOTILHO, José Joaquim Gomes. Direito constitucional e teoria da Constituição. 7 ed. Lisboa: Almedina, 2003.

36 GINSBURG, Tom; VERSTEEG, Mila. Why do countries adopt constitutional review? Journal of Law, Economics and Organization, Oxford, v. 30, n. 3, p. 587, 2014; FAVOREU, Louis. Constitutional courts. Baton Rouge: Center of Civil Law Studies - LSU Law Center, 2001. Disponível em: <http://books.google.com.br/books?id=CVxQAQAAIAAJ\&q=louis+favoreu+2001\&dq=louis + favoreu+2001\&hl=en\&sa=X\&ei=tUnlU9OVBo7ksATql4CoBQ\&ved=0CBsQ6AEwAA>. Acesso em: 3 abr. 2014.

37 GINSBURG, Tom; VERSTEEG, Mila. Why do countries adopt constitutional review? Journal of Law, Economics and Organization, Oxford, v. 30, n. 3, p. 587, 2014.

38 Corresponding to countries like Colombia, Venezuela, Ecuador and Panama.

39 SCHOR, Miguel. Constitutionalism Through the Looking Glass of Latin America. Texas International Law Journal, Austin, v. 41, n. 1, p. 1-35, 2005. p. p. 15-20; JACKSON, Vicki C.; TUSHNET, Mark. Comparative constitutional law. 2. ed. New York: Foundation Press, 2006.

40 JACKSON, Vicki C.; TUSHNET, Mark. Comparative constitutional law. 2. ed. New York: Foundation Press, 2006.

41 HELMKE, Gretchen; RIOS-FIGUEROA, Julio. Courts in Latin America. Cambridge: Cambridge University Press, 2011. 
This Latin American blend of centralized and decentralized systems created what many scholars call hybrid or mixed judicial review systems. ${ }^{42}$

Jackson and Tushnet affirm that hybrid systems also exist, where all judgments and courts can refuse to apply unconstitutional laws, but there is also a special court with the specific function of exercising judicial review. ${ }^{43}$ Brewer-Carias gave special emphasis to the mixed model, calling it a "Latin American contribution" to judicial review and stating that Latin America "deserves the credit for having originated hybrid systems in the 19th century". ${ }^{44}$ Louis Favoreau also understands that, in addition to the American and European models, there is a Latin American ${ }^{45}$ model of judicial review. ${ }^{46}$

In Brazil, judicial review of legislation started diffusely and, especially under the 1988 Constitution, amplified the role of Supremo Tribunal Federal of the Constitutional Court. However, the large volume of "recursos extraordinários" led the Brazilian Supreme Court into a serious crisis due to the risk of not only being unable to fulfill its constitutional role but also its failure as institution. ${ }^{47}$ With the "repercussão geral" 48 requirement, the Brazilian Supreme Court attempted to deal with its enormous volume of cases, trying to diminish its dysfunctional character.

Regarding the types of constitutional adjudication, the Brazilian system can be considered a mixed or hybrid model. Judicial review can be exercised by all judges and tribunals along the entire judicial hierarchy of the nation, mainly in concrete review cases. The Federal Supreme Court plays a very special role, not only as the last court of appeal in the hierarchy of the nation but also as a constitutional court. Both concrete and abstract review are within the jurisdiction of the Supreme Court; however, abstract review is not open to everyone but only to few political actors, such as the federal and state governments, the prosecutor general, the heads of the senate and the house of

42 BREWER-CÁRIAS, Allan-Randolph. Reflexiones sobre el constitucionalismo en América. Caracas: Jurídica Venezoelana, 2001; JACKSON, Vicki C.; TUSHNET, Mark. Comparative constitutional law. 2. ed. New York: Foundation Press, 2006.

43 JACKSON, Vicki C.; TUSHNET, Mark. Comparative constitutional law. 2. ed. New York: Foundation Press, 2006. p. 466.

44 BREWER-CÁRIAS, Allan-Randolph. Reflexiones sobre el constitucionalismo en América. Caracas: Jurídica Venezoelana, 2001. p. 33.

45 Scholars (RÍOS-FIGUEROA, Julio. Institutions for Constitutional Justice in Latin America. In: HELMKE, Gretchen; RIOS-FIGUEROA, Julio. Courts in Latin America. Cambridge: Cambridge University Press, 2011, p. 32) usually consider Latin America a group of eighteen countries, which excludes Cuba. This group includes Argentina, Bolivia, Brazil, Chile, Costa Rica, Colombia, Dominican Republic, Ecuador, El Salvador, Guatemala, Honduras, Mexico, Nicaragua, Panama, Paraguay, Peru, Uruguay and Venezuela.

46 FAVOREU, Louis. Constitutional courts. Baton Rouge: Center of Civil Law Studies - LSU Law Center, 2001. Disponível em: <http://books.google.com.br/books?id=CVxQAQAAIAAJ\&q=louis+favoreu+2001\&dq=louis +favoreu+2001\&hl=en\&sa=X\&ei=tUnlU9OVBo7ksATql4CoBQ\&ved=0CBsQ6AEwAA>. Acesso em: 3 abr. 2014. p. 125.

47 ALVES, José Carlos Moreira. Poder judiciário. Revista dos Tribunais, São Paulo, ano 5, n. 18, p. 269, jan./mar. 1997.

48 Created by constitutional amendment n. 45/2004. 
representatives, represented political parties, the Brazilian Bar Association and confederations or national unions. Brazilian constitutional review can be characterized as an a posteriori system, as adjudication is conducted after the legislation is implemented. ${ }^{49}$

Colombia is a good example of "the mosaic ${ }^{\prime \prime 50}$ of constitutional adjudication that characterizes Latin America.

On one hand, similar to the Brazilian model, Colombia practices concrete, diffused, a posteriori review when an individual files a petition (for example, recurso de amparo or acción de tutela) at a lower level of the judicial hierarchy when he or she considers the law (or other decree) unconstitutional because it violates his or her constitutional rights. ${ }^{51}$ However, unlike what occurs in Brazil, in Colombia, as noted by Juan Carlos Rodríguez-Raga, "the Colombian Constitutional Court may choose to review any lower-court decision on a petition, having therefore, the ability to discretionally grant certiorari to a case and settings its own agenda".52

On the other hand, the Colombian Constitutional Court practices abstract constitutional review. Such a review can be a priori or a posteriori, ${ }^{53}$ including the analysis of laws before or after promulgation. Such a review can address not only to laws but also international treaties, executive emergency decrees, and statutes. Unlike the Brazilian system, the Colombian Constitutional Court can act ex officio, without provocation, especially with regard to a priori reviews.

Regarding a posteriori abstract reviews in Colombia, the main procedural instrument is the API - Acción Pública de Inconstitucionalidad, which is Spanish for "public action of unconstitutionality"; this can be a claim against ordinary bills, executive ordinary (delegated) decrees, and constitutional amendments. However, again, unlike the Brazilian system, where standing to address abstract constitutional questions to the Supreme Court (STF) is closed to a specific list of political actors, the Colombian API can be filed by any citizen and with very few formalities. ${ }^{54}$ In fact, as noted by Cepeda,

49 MENDES, Gilmar Ferreira. Estado de direito e jurisdição constitucional 2002-2010. São Paulo: Saraiva, 2011. p. 1125; BARROSO, Luíz Roberto. O controle de constitucionalidade no direito brasileiro. 4. ed. São Paulo: Saraiva, 2011. p. 87.

50 RÍOS-FIGUEROA, Julio. Institutions for Constitutional Justice in Latin America. In: HELMKE, Gretchen; RIOS-FIGUEROA, Julio. Courts in Latin America. Cambridge: Cambridge University Press, 2011.

51 RODRIGUEZ-RAGA, Juan Carlos. Strategic Deference in the Colombian Constitutional Court, 1992-2006. In: HELMKE, Gretchen; RIOS-FIGUEROA, Julio. Courts in Latin America. Cambridge: Cambridge University Press, 2011. p. 83.

52 RODRIGUEZ-RAGA, Juan Carlos. Strategic Deference in the Colombian Constitutional Court, 1992-2006. In: HELMKE, Gretchen; RIOS-FIGUEROA, Julio. Courts in Latin America. Cambridge: Cambridge University Press, 2011. p. 82.

53 A posteriori abstract review is mainly exercised through APIs, which stands for Acción Pública de Inconstitucionalidad, Spanish for "public action of unconstitutionality".

54 RODRIGUEZ-RAGA, Juan Carlos. Strategic Deference in the Colombian Constitutional Court, 1992-2006. In: HELMKE, Gretchen; RIOS-FIGUEROA, Julio. Courts in Latin America. Cambridge: Cambridge University Press, 2011. p. 82. 
Colombia is famous as "the most open and accessible constitutional review system in the Western World".55

Although abstract review plays a large role in the Colombian Constitutional Court system, a great number of cases in the court's dockets are based on concrete review, especially the "tutelas", which have become a major instrument for protecting citizen's constitutional rights.

According to the information found in the Constitutional Court's website, ${ }^{56}$ from 1992 to 2018, the court judged 25,182 cases, including 18,843 sentences on the procedure of acción de tutela (80.5\%) and 6,339 decisions in abstract reviews (acción pública de inconstitucionalidad) (25\%).

The numbers in Brazil are dramatically higher than those in Colombia. The Federal Supreme Court of Brazil, in 2018 alone (until sept. $2^{\text {nd }}$ ), decided 84,950 cases, including 64,681 "recursos extraordinários" (extraordinary appeals) or related "agravos".57 In less than one year, the Brazilian Supreme Court decided over three times the number of cases as the Colombian Constitutional Court in 26 years. The alarming number of cases that reach and are decided by the Supreme Court explains a large part of the dysfunctional character of the court..$^{58}$

After this view of the Brazilian and Colombian jurisdictional systems, we will analyze the criteria of "autonomy" and "authority", specifically with regard to the actual protection of rights and the role played by the Colombian Constitutional Court and the Brazilian Federal Supreme Court through their jurisdictional procedures.

\section{THE CRITERIA OF AUTONOMY AND AUTHORITY OF CONSTITU- TIONAL AND SUPREME COURTS AND THE INSTRUMENTS USED BY THE COLOMBIAN CONSTITUTIONAL COURT AND THE BRA- ZILIAN FEDERAL SUPREME COURT}

Why can some supreme or constitutional courts protect social and individual rights in a more effective way than others?

\footnotetext{
55 CEPEDA Apud RODRIGUEZ-RAGA, Juan Carlos. Strategic Deference in the Colombian Constitutional Court, 1992-2006. In: HELMKE, Gretchen; RIOS-FIGUEROA, Julio. Courts in Latin America. Cambridge: Cambridge University Press, 2011. p. 82.

56 COLOMBIA. Colombian Constitutional Court. Available at: <http://www.corteconstitucional.gov.co/relatoria/estadisticas.php>. Last accessed: 30 aug. 2018.

57 BRAZIL. Supreme Federal Court. Available at: <http://www.stf.jus.br/portal/cms/verTexto.asp?servico=estatistica\&pagina=decisoesinicio >. Last accessed: 30 aug. 2018.

58 As an attempt to solve this problem, most of the judgements by the STF are not decided by the full court. The majority of the decisions are constructed by the Justice-Rapporteur (assigned Justice). This problem is pointed out by Juliano Benvindo in BENVINDO, Juliano Zaiden. Do solipsismo supremo à deliberação racional. Direito, Estado e Sociedade, Rio de Janeiro, n. 50, p. 149-178, jan./jun. 2017. p. 174. According to Benvindo, in 2015 , the STF produced a total of 116,669 decisions but only 17,752 as a full body (p. 175).
} 
There have been some institutional explanations from scholars in comparative constitutional law that are starting to be tested by empirical studies. ${ }^{59}$ Although there are still a small number of papers that examine the protection of rights by constitutional or supreme courts from a comparative perspective, such works are beginning to emerge, including studies on Latin America. ${ }^{60}$ These studies take into account two broad dimensions in measuring the role played by the court: autonomy (or independence) and authority (or power). ${ }^{61}$

The criterion of autonomy or independence can be understood as the "judge`s freedom to decide according to his or her own sense of what the law requires" 62 or, in other words, "the ability and willingness of courts to decide cases in light of the law without undue regard to the views of other government actors".63

Daniel Brinks and Abby Blass divide the criteria of autonomy into two different dimensions: ex ante and ex post autonomy. Ex ante autonomy "is concerned with pluralism in the process of appointing justices, and with the ability of a single outside actor to control appointments". Ex post autonomy "measures the extent to which a single actor can shape and manipulate the incentives of sitting justices". ${ }^{64}$

The criteria of ex ante and ex post autonomy are very important for the role played by the constitutional or supreme court (as an institution) and its members (individually), but the present article will focus specifically on another important aspect of the criterion of authority: the standing to file constitutional claims with the court.

As pointed out by Brinks and Blass, even "the most autonomous and unaccountable court in the world will not be an influential political force if it is difficult to access or lacks the tools to act decisively on a wide range of issues".65 This perspective is the reason for the importance of the dimension of authority.

59 GINSBURG, Tom; VERSTEEG, Mila. Why do countries adopt constitutional review? Journal of Law, Economics and Organization, Oxford, v. 30, n. 3, p. 587, 2014.

60 HELMKE, Gretchen; RIOS-FIGUEROA, Julio. Courts in Latin America. Cambridge: Cambridge University Press, 2011.

61 BRINKS, Daniel.; BLASS, Abby. Rethinking Judicial Empowerment: The New Foundations of Constitutional Justice. International Journal of Constitutional Law, Oxford, v. 15, n. 2, p. 296-331, apr. 2017; HELMKE, Gretchen; RIOS-FIGUEROA, Julio. Courts in Latin America. Cambridge: Cambridge University Press, 2011; RIOSFIGUEROA, Julio. Institutions for Constitutional Justice in Latin America. In: HELMKE, Gretchen; RIOS-FIGUEROA, Julio. Courts in Latin America. Cambridge: Cambridge University Press, 2011; GINSBURG, Tom; VERSTEEG, Mila. Why do countries adopt constitutional review? Journal of Law, Economics and Organization, Oxford, v. 30, n. 3, p. 587, 2014.

62 BRINKS, Daniel.; BLASS, Abby. Rethinking Judicial Empowerment: The New Foundations of Constitutional Justice. International Journal of Constitutional Law, Oxford, v. 15, n. 2, p. 296-331, apr. 2017. p. 306.

63 STATON, Jeffrey; MOORE, Will. Judicial Power in Domestic and International Politics, International Organization, Cambridge, v. 65, n. 3, 2011, p. 553-587.

64 BRINKS, Daniel.; BLASS, Abby. Rethinking Judicial Empowerment: The New Foundations of Constitutional Justice. International Journal of Constitutional Law, Oxford, v. 15, n. 2, p. 296-331, apr. 2017. p. 296.

65 BRINKS, Daniel.; BLASS, Abby. Rethinking Judicial Empowerment: The New Foundations of Constitutional Justice. International Journal of Constitutional Law, Oxford, v. 15, n. 2, p. 296-331, apr. 2017. p. 311. 
Authority or power is a dimension that "evaluates the court's ability to intervene decisively on a broad range of politically relevant issues, on behalf of a broad range of actors".66

This dimension can be seen in three domains: a court's formal toolkit, its accessibility, and its decisive capacity. ${ }^{67}$

The first includes all the main elements that define the scope of the court's jurisdiction, such as the nature and number of rights it adjudicates and other powers it might have beyond deciding cases (like impeaching presidents or supervising elections). The second involves the nature and number of actors that are entitled to bring cases before the court and the procedural instruments (mechanisms) used to access the court. The third and final aspect relates to the effect of the court's judgments: whether the decisions have general binding effects (erga omnes) or just inter partes effects. ${ }^{68}$

The present article aims to examine the second abovementioned aspect of authority: the different types of procedural instruments used to access the Colombian Constitutional Court and the Brazilian Supreme Court and, in particular, the accessibility in each system (who can bring constitutional claims to the courts). The main purpose is to discuss the accessibility of the Colombian Constitutional Court and the Brazilian Federal Supreme Court and how this accessibility might affect the role performed by each court in terms of the protection of social and individual rights.

Thus, based on the classification proposed by Cappelletti ${ }^{69}$ and taking the range of models and institutions created throughout the development of constitutionality control ${ }^{70}$ we can distinguish four basic revision tools: (1) concrete and concentrated, a posteriori; (2) concrete and diffuse (decentralized), a posteriori; (3) abstract and concentrated (centralized), a priori; and (4) abstract and concentrated (centralized), a posteriori. $^{71}$

\footnotetext{
66 BRINKS, Daniel.; BLASS, Abby. Rethinking Judicial Empowerment: The New Foundations of Constitutional Justice. International Journal of Constitutional Law, Oxford, v. 15, n. 2, p. 296-331, apr. 2017. p. 296.

67 BRINKS, Daniel.; BLASS, Abby. Rethinking Judicial Empowerment: The New Foundations of Constitutional Justice. International Journal of Constitutional Law, Oxford, v. 15, n. 2, p. 296-331, apr. 2017. p. 311.

68 BRINKS, Daniel.; BLASS, Abby. Rethinking Judicial Empowerment: The New Foundations of Constitutional Justice. International Journal of Constitutional Law, Oxford, v. 15, n. 2, p. 296-331, apr. 2017. p. 311.

69 CAPPELLETTI, Mauro. $\mathbf{O}$ controle judicial de constitucionalidade das leis no direito comparado. Tradução de Aroldo Plínio Gonçalves. 2. ed. reimpressão. Porto Alegre: Sergio Antonio Fabris, 1999.

70 SWEET, Alec Stone. Governing with judges: Constitutional Politics in Europe. New York: Oxford University Press, 2000. p. 107-112.

71 RÍOS-FIGUEROA, Julio. Institutions for Constitutional Justice in Latin America. In: HELMKE, Gretchen; RIOS-FIGUEROA, Julio. Courts in Latin America. Cambridge: Cambridge University Press, 2011. p. 41.
} 


\section{(1) concrete-centralized-a posteriori}

In concrete instruments of centralized a posteriori review, such as the Spanish amparo, the German Verfassungsbescwerde or the Mexican controversia constitutional, decisions can have either erga omnes or inter partes effects, or the instruments can be open to all citizens or restricted to public authorities. ${ }^{72}$ We do not see very clear procedural instruments of concrete-centralized-a posteriori review either in the Brazilian $^{73}$ or the Colombian systems.

\section{(2) concrete-decentralized-a posteriori}

The second instrument, concrete-decentralized-a posteriori, corresponds to the Mexican amparo, the Colombian tutela, the Brazilian mandado de segurança, or the Anglo-Saxon habeas corpus. As a decentralized procedure, it can be heard by any judge, and the decisions, generally, have inter partes effects. Usually, instruments of this kind are open to every citizen. If the decisions are appealed and reach the supreme court or the instrument is presented directly to the supreme or constitutional court the judgments may acquire general effects. ${ }^{74}$

The Colombian tutela is an instrument that is open to all citizens, and despite the fact that it has inter partes effects, the ratio decidendi from the decision of the Constitutional Court is binding, affecting the whole society. ${ }^{75}$ Specifically, when the Court declares an "unconstitutional state of affairs" through the tutela, it gives "general validity to its rulings".

Diffuse-concrete-a posteriori instruments under the jurisdiction of the Brazilian Supreme Court, such as mandado de segurança or habeas corpus, have inter partes effects. On the other hand, recursos extraordinários with recognized repercussão geral (general repercussion) have general effects. Recursos extraordinários (extraordinary appeals) and related Agravos constitute the greatest number of cases on the court's

\footnotetext{
72 RÍOS-FIGUEROA, Julio. Institutions for Constitutional Justice in Latin America. In: HELMKE, Gretchen; RIOS-FIGUEROA, Julio. Courts in Latin America. Cambridge: Cambridge University Press, 2011. p. 42.

73 Initially, we may consider the Brazilian "reclamação" a concrete-centralized-a posteriori instrument. It is indeed a concrete instrument through which the court can analyze the facts of a case or controversy (it is not an abstract instrument). It can be also considered an a posteriori mechanism because it is not dedicated to analyzing laws that have not already been promulgated. However, the "reclamação" is not an exclusive instrument of the Supreme Court's jurisdiction; in Brazil, "reclamações" can be addressed to various courts. Therefore, it cannot be considered a centralized instrument.

74 RÍOS-FIGUEROA, Julio. Institutions for Constitutional Justice in Latin America. In: HELMKE, Gretchen; RIOS-FIGUEROA, Julio. Courts in Latin America. Cambridge: Cambridge University Press, 2011. p. 42.

75 COLOMBIA. Colombian Constitutional Court, Judgement T-233, 04/20/17. Available at: <https://www.ambitojuridico.com/noticias/general/constitucional-y-derechos-humanos/aunque-fallos-de-revision-de-tutela-tengan>. Last accessed: 15 aug. 2018.
} 
docket, which led Justice Moreira Alves to pronounce that "the crisis of the Federal Supreme Court is the crisis of the extraordinary appeals".76

\section{(3) abstract-centralized-a priori}

The classic decisions of the French Conseil Constitutionnel are the prototypical example of abstract-centralized-a priori instruments. These instruments must have erga omnes effects because the procedure focuses on quality control for the lawmaking process. Generally, instruments of this kind are not open to every citizen. ${ }^{77}$

However, it is interesting to point out that the Colombian API - Acción Pública can be "automatic", functioning as an instrument to control the constitutionality of a law without the need for an action by a plaintiff. ${ }^{78}$ Therefore, this instrument plays a very similar role as the typical a priori French review system in this case.

In Brazil, there are no instruments of this kind.

\section{(4) abstract- centralized-a posteriori}

The fourth type of instrument, abstract-centralized-a posteriori, such as the Mexican acción de inconstitucionalidad, the Colombian acción pública de inconstitucionalidad, or the German abstraktes Normkontrollverfahren, is based on the Kelsenian classic ${ }^{79}$ model of judicial review.

The Brazilian system, currently, has several instruments of this kind: ação direta de inconstitucionalidade (direct action of unconstitutionality), ação declaratória de constitucionalidade (declaratory action of constitutionality), arguição de descumprimento de preceito fundamental (action of noncompliance with basic precept) and ação de inconstitucionalidade por omissão (action of unconstitutionality for omission).

However, unlike the Colombian acción pública de inconstitucionalidad, which is open to all citizens, Brazilian abstract instruments of centralized constitutional review are only available to a few political or associated actors. ${ }^{80}$

\footnotetext{
76 ALVES, José Carlos Moreira. Poder judiciário. Revista dos Tribunais, São Paulo, ano 5, n. 18, p. 269, jan./mar. 1997.

77 RÍOS-FIGUEROA, Julio. Institutions for Constitutional Justice in Latin America. In: HELMKE, Gretchen; RIOS-FIGUEROA, Julio. Courts in Latin America. Cambridge: Cambridge University Press, 2011. p. 42.

78 RÍOS-FIGUEROA, Julio. Institutions for Constitutional Justice in Latin America. In: HELMKE, Gretchen; RIOS-FIGUEROA, Julio. Courts in Latin America. Cambridge: Cambridge University Press, 2011. p. 42.

79 The model established by the Austrian Constitution of 1920 uses abstract review, which is different from the model of the Verfassunsgnovelle (1929) that added concrete review to the abstract review. (KELSEN, Hans. Jurisdição constitucional. São Paulo: Martins Fontes, 2007)

80 The federal and state governments, the general prosecutor, the heads of the senate and of the house of representatives, represented political parties, the Brazilian Bar Association and confederations or national unions.
} 


\section{THE EFFECTIVE PROTECTION OF SOCIAL AND INDIVIDUAL RI- GHTS BY THE BRAZILIAN SUPREME COURT AND COLOMBIAN CONSTITUTIONAL COURT AND ITS RELATION TO THE STAN- DING TO BRING A CONSTITUTIONAL LAWSUIT TO THESE BO- DIES}

Recent studies are beginning to provide data on the effective role played by constitutional or supreme courts around the world. In particular, in Latin America, there are amazing empirical studies that locally or regionally disclose which or whose rights are being protected.

Our paper aims to analyze the protection of social and individual rights in Brazil and Colombia by the Colombian Constitutional Court and Brazilian Supremo Tribunal Federal.

According to Adam Clinton and Mila Versteeg, "social rights are also individual rights. They are individual entitlements that are not typically enjoyed in groups". The authors exemplify this statement using the right to education, which "entitles individuals to have access to schooling", or the right to healthcare, which "grants individuals a right to access basic types of healthcare. ${ }^{81}$

A very broad study involving all Direct Actions of Unconstitutionality, decided by the Brazilian Supremo Tribunal Federal from 1988 to 2012, demonstrated that "more than protecting basic rights and guarantees, the centralized system of judicial review is an instrument for the protection of corporative interests, showing thereby a clear dissonance between the mainstream literature and the judicial practice". 82

Another study conducted by Juliano Benvindo of the University of Brasilia concluded that "acting as a Constitutional Court, the Court has done little in terms of guarding the Constitution or defending minorities, as proven here empirically". ${ }^{83}$

Diana Kapiszewski, in her paper on the Brazilian Supreme Court, is emphatic that "case evidence suggests that the STF played a less active role in the rights realm: the sample under study contains a few important cases regarding emerging SE rights" and "the Court did not consistently enforce rights". ${ }^{4}$

81 CLINTON, Adam; VERSTEEG, Mila. Rights without resources: the impact of constitutional social rights on social spending. Law and Economics Research Paper Series, Charlottesville, out. 2016. Disponível em: <http:// ssrn.com/abstract=2857731>. Acesso em 30 ago. 2018. p. 11.

82 COSTA, Alexandre Araújo; BENVINDO, Juliano Zaiden. A quem interessa o controle concentrado de constitucionalidade? O descompasso entre teoria e prática na defesa de direitos fundamentais. 2013. Disponível em: <https://papers.ssrn.com/sol3/papers.cfm?abstract_id=2509541>. Acesso em 14 ago. 2018. p. 1.

83 BENVINDO, Juliano Zaiden. A 'última palavra', o poder e a história: O Supremo Tribunal Federal e o discurso de supremacia no constitucionalismo brasileiro. Revista de informação legislativa, Brasília, v. 51, n. 201, p. 71-95, jan./mar. 2014. p. 92)

${ }^{84}$ Kapiszewski presents some hypotheses to explain the weak protection of social rights by the STF: "Though the lack of mechanisms to file rights claims directly with the high court and weak support structures for 
Daniel M. Brinks, analyzing the role played by the Brazilian STF, takes a more optimistic view of the court in terms of the protection of rights. The scholar thinks that the Brazilian Supreme Court is "moderately able" to protect rights and police the separation of powers ("ventilate separation of power disputes"). Brinks states that STF justices are "protective of settled constitutional structures and understandings, including notions of due process and basic first-generation rights" but "cautious in embracing positive rights claims". ${ }^{85}$

Gretchen Helmke and Julio Ríos-Figueroa, comparing all 18 countries in Latin America, concludes that Colombian judges and, increasingly, Brazil's magistrates "are among the major political players, capable or shaping the most important political issues of the day".86 The main difference is that, unlike Colombia, Brazil's judiciary, especially its Supreme Court, is much more willing to solve interbranch or federal disputes and protect corporate interests than it is to adjudicate social and individual rights. ${ }^{87}$

The Colombian Constitutional Court and Costa Rica`s Sala Cuarta, "have been willing and able to both to enforce rights and to arbitrate interbranch relations".88

In a different way, the Brazilian STF and other courts, such as the Chilean and Mexican Supreme Courts, "staked their reputations on arbitrating interbranch disputes but have largely eschewed the role of rights protector".89

Focusing specifically on the analyzes of the Colombian Constitutional Court, Juan Carlos Rodrígues-Raga concludes that "overall, from a comparative perspective, the Colombian Constitutional Court has earned a well-deserved reputation for its

constitutional rights adjudication help to explain why the STF did not receive more rights cases, those factors do not account for the STF's meek rulings on the rights cases it did decide. (...) In combination, pragmatism ("economic and political realities") and remnant conservatism likely dampened enthusiasm for rights protection on the few broad-based rights cases the STF received and decided in the early post transition period." (KAPISZEWSKI, Diana. Power Broker, Policy Maker, or Rights Protector: The Brazilian Supremo Tribunal Federal in Transition. In: HELMKE, Gretchen; RIOS-FIGUEROA, Julio. Courts in Latin America. Cambridge: Cambridge University Press, 2011. p. 170-174).

85 BRINKS, Daniel. "Faithful Servants of the Regime". The Brazilian Constitutional Court's Role under 1988 Constitution. In: HELMKE, Gretchen; RIOS-FIGUEROA, Julio. Courts in Latin America. Cambridge: Cambridge University Press, 2011. p. 147.

86 HELMKE, Gretchen; RIOS-FIGUEROA, Julio. Courts in Latin America. Cambridge: Cambridge University Press, 2011. p. 21.

87 COSTA, Alexandre Araújo; BENVINDO, Juliano Zaiden. A quem interessa o controle concentrado de constitucionalidade? O descompasso entre teoria e prática na defesa de direitos fundamentais. 2013. Disponível em: <https://papers.ssrn.com/sol3/papers.cfm?abstract_id=2509541>. Acesso em 14 ago. 2018; KAPISZEWSKI, Diana. Power Broker, Policy Maker, or Rights Protector: The Brazilian Supremo Tribunal Federal in Transition. In: HELMKE, Gretchen; RIOS-FIGUEROA, Julio. Courts in Latin America. Cambridge: Cambridge University Press, 2011; HELMKE, Gretchen; RIOS-FIGUEROA, Julio. Courts in Latin America. Cambridge: Cambridge University Press, 2011. p. 23.

88 HELMKE, Gretchen; RIOS-FIGUEROA, Julio. Courts in Latin America. Cambridge: Cambridge University Press, 2011. p. 23.

89 HELMKE, Gretchen; RIOS-FIGUEROA, Julio. Courts in Latin America. Cambridge: Cambridge University Press, 2011. p. 23. 
autonomy" and "occupies a central position in the Colombian political arena and plays a vital role for the protection of citizen rights".90

In "Rethinking judicial empowerment: The new foundations of constitutional justice", Daniel Brinks and Abby Blass apply the criteria of autonomy (ex ante and ex post) and authority to evaluate all the constitutional models in Latin America from 1975 to $2009 .^{91}$

Regarding authority and, more specifically, the criteria of standing to present constitutional claims before the courts, the collected data review a particularly special role played by the Colombian Constitutional Court.

The research states that "Colombia, by most accounts the country with the most active and consequential court in the entire region, has the court with the highest degree of authority among the group, coupled with high levels of autonomy".92

Brazil's STF, in more recent years, has also been considered a "significant player" in the major policy disputes in the country, ${ }^{93}$ but as mentioned previously, it is better at resolving interbranch disputes than it is at enforcing social rights.

The Colombian Constitutional Court, like the Supreme Court of Costa Rica, "exhibits independence vis-à-vis the executive" and "tried to compensate for the predominance of the President and the deficit of political control by the Parliament, with a strong review of economic and social policies and programs"..$^{94}$

According to Carlos Bernal-Pulido, the Colombian Constitutional Court began to play this role specifically "due to the existence of public standing of individuals to take

90 RODRIGUEZ-RAGA, Juan Carlos. Strategic Deference in the Colombian Constitutional Court, 1992-2006. In: HELMKE, Gretchen; RIOS-FIGUEROA, Julio. Courts in Latin America. Cambridge: Cambridge University Press, 2011. p. 96.

91 BRINKS, Daniel.; BLASS, Abby. Rethinking Judicial Empowerment: The New Foundations of Constitutional Justice. International Journal of Constitutional Law, Oxford, v. 15, n. 2, p. 296-331, apr. 2017.

92 BRINKS, Daniel.; BLASS, Abby. Rethinking Judicial Empowerment: The New Foundations of Constitutional Justice. International Journal of Constitutional Law, Oxford, v. 15, n. 2, p. 296-331, apr. 2017. p. 319.

93 BRINKS, Daniel.; BLASS, Abby. Rethinking Judicial Empowerment: The New Foundations of Constitutional Justice. International Journal of Constitutional Law, Oxford, v. 15, n. 2, p. 296-331, apr. 2017. p. 319.

94 Carlos Bernal-Pulido also includes "the current Brazilian Supreme Court" as an example of a court that is independent from the executive and has "a Strong review of economic and social policies and programs". (BERNAL-PULIDO, Carlos. The constitutional protection of economic and social rights in Latin America. In: DIXON, Rosalind; GINSBURG, Tom (Eds.). Comparative constitutional law in Latin America. Cheltenham: Edward Elgar Publishing, 2017. p. 16) Although we agree that the current STF shows a relatively strong level of independence, other studies (BENVINDO, Juliano Zaiden. A 'última palavra', o poder e a história: O Supremo Tribunal Federal e o discurso de supremacia no constitucionalismo brasileiro. Revista de informação legislativa, Brasília, v. 51, n. 201, p. 71-95, jan./mar. 2014; HELMKE, Gretchen; RIOS-FIGUEROA, Julio. Courts in Latin America. Cambridge: Cambridge University Press, 2011) show that Brazilian Supreme Court has been strong in deciding interbranch and political disputes but not in enforcing social and individual rights. 
economic and social rights cases to jurisdiction by means of writs, such as the Colombian Acción de Tutela". ${ }^{95}$

There is a large contrast between the many procedures of abstract review in Brazil and the sole abstract action available in the Colombian system. The difference in the number of instruments may give the initial idea that rights are better protected by the various Brazilian instruments.

However, when we observe that the access to using these procedures in Brazil is limited to political authorities, ${ }^{96}$ the national Bar Association and confederations or national unions and compare this situation to the open access to every Colombian citizen to file an acción púbica de inconstitucionalidad with the Colombian Constitutional Court, ${ }^{97}$ it becomes clear why we believe there is greater access to social and individual rights through the Colombian Constitutional Court and why these same rights are more effectively protected in Colombia.

As pointed out before in this paper, recent empirical research developed by the University of Brasilia Law School, which examined all the ADIs (ações diretas de inconstitucionalidade) decided by the Brazilian Supreme Court (STF) until 2012, came to the conclusion that the court, through abstract review, does not effectively protect individual or social rights. ${ }^{98}$

We do not yet have data on the protection of rights by the STF through concrete review procedures, but studies that do not distinguish between modes of constitutional review have stated that the Brazilian Supreme Court does not effectively protect social or individual rights. ${ }^{99}$

Costa and Benvindo's research comes to a similar conclusions as those in other comparative constitutional law studies: abstract control of constitutionality is a good way to resolve political disputes but not to protect rights. ${ }^{100}$ On the other hand, accor-

95 BERNAL-PULIDO, Carlos. The constitutional protection of economic and social rights in Latin America. In: DIXON, Rosalind; GINSBURG, Tom (Eds.). Comparative constitutional law in Latin America. Cheltenham: Edward Elgar Publishing, 2017. p. 16.

96 Abstract review of constitutionality before the Supremo Tribunal Federal can only be requested by the federal and state governments, the prosecutor general, the heads of the senate and of the house of representatives, represented political parties, the Brazilian Bar Association and confederations or national unions.

97 RÍOS-FIGUEROA, Julio. Institutions for Constitutional Justice in Latin America. In: HELMKE, Gretchen; RIOS-FIGUEROA, Julio. Courts in Latin America. Cambridge: Cambridge University Press, 2011. p. 49.

98 COSTA, Alexandre Araújo; BENVINDO, Juliano Zaiden. A quem interessa o controle concentrado de constitucionalidade? O descompasso entre teoria e prática na defesa de direitos fundamentais. 2013. Disponível em: <https://papers.ssrn.com/sol3/papers.cfm?abstract_id=2509541>. Acesso em 14 ago. 2018. p. 74-80.

99 BRINKS, Daniel.; BLASS, Abby. Rethinking Judicial Empowerment: The New Foundations of Constitutional Justice. International Journal of Constitutional Law, Oxford, v. 15, n. 2, p. 296-331, apr. 2017; KAPISZEWSKI, Diana. Power Broker, Policy Maker, or Rights Protector: The Brazilian Supremo Tribunal Federal in Transition. In: HELMKE, Gretchen; RIOS-FIGUEROA, Julio. Courts in Latin America. Cambridge: Cambridge University Press, 2011. p. 23.

100 RÍOS-FIGUEROA, Julio. Institutions for Constitutional Justice in Latin America. In: HELMKE, Gretchen; RIOS-FIGUEROA, Julio. Courts in Latin America. Cambridge: Cambridge University Press, 2011. p. 43. 
ding to these studies, instruments of concrete review are better suited to the defense of rights. ${ }^{101}$

Of course, this finding does not mean that all concrete procedures of judicial review, centralized or uncentralized, lead to good levels of protection of social and individual rights or that abstract procedures of judicial review are not able to protect rights. The issue is much more complex than that. However, the studies show a tenden$c y$, which has been observed in the various judicial review mechanisms - that concrete procedures tend to protect rights in a more effective way than abstract ones.

The explanation for this phenomenon may lie in the access to constitutional or the supreme courts. Concrete procedures could be seen as better instruments to protect individual or social rights because they allow individuals - as long as the mechanism is open to general citizens - to bring constitutional claims related to violations of their own rights.

The mixed system of instruments in the Colombian Constitutional Court, especially the tutelas (concrete instrument) and the acción pública de inconstitucionalidad (abstract instrument), makes the court capable of effectively protecting social and individual rights.

The Colombian Constitutional Court is known as one of the strongest tribunals in terms of the protection of fundamental rights, especially those related to individual and social rights. According to the court, there is an absolute minimum "below which each citizen has a constitutional right to enjoy the necessary means for a basic level of subsistence".102

As observed by Carlos Bernal, "the minimum core is different from reasonableness" 103 . While reasonableness is based on the idea that only the executive and legislature are empowered to stablish the minimum amount and judges should be deferential to this determination unless it is unreasonable, the minimum core doctrine states that

\footnotetext{
101 RÍOS-FIGUEROA, Julio. Institutions for Constitutional Justice in Latin America. In: HELMKE, Gretchen; RIOS-FIGUEROA, Julio. Courts in Latin America. Cambridge: Cambridge University Press, 2011. p. 43; RODRIGUEZ-RAGA, Juan Carlos. Strategic Deference in the Colombian Constitutional Court, 1992-2006. In: HELMKE, Gretchen; RIOS-FIGUEROA, Julio. Courts in Latin America. Cambridge: Cambridge University Press, 2011; ROSENBERG, Gerald. The Hollow Hope: Can Courts bring about social change? Chicago: University of Chicago Press. 1991, p. 18; SWEET, Alec Stone. Governing with judges: Constitutional Politics in Europe. New York: Oxford University Press, 2000. p. 107-112.

102 BERNAL-PULIDO, Carlos. The constitutional protection of economic and social rights in Latin America. In: DIXON, Rosalind; GINSBURG, Tom (Eds.). Comparative constitutional law in Latin America. Cheltenham: Edward Elgar Publishing, 2017. p. 11.

103 BERNAL-PULIDO, Carlos. The constitutional protection of economic and social rights in Latin America. In: DIXON, Rosalind; GINSBURG, Tom (Eds.). Comparative constitutional law in Latin America. Cheltenham: Edward Elgar Publishing, 2017. p. 11.
} 
courts can "determine the minimum amount and quality of goods and services that political authorities should deliver to the individuals".104

The Colombian Constitutional Court's case law offers a great number of examples of the use of the minimum core doctrine (see, the judgments: SU-559/1997, T-068/1998, T-153/1998, SU-090/2000, T-068/2010, T-025/2004 and T-760/2008). For example, concerning the right to water, the court decided that every citizen should receive a minimum amount of clean water daily (see, the judgment T-740/2011). In the same sense, when applied to the right to health, the court determined that the government must guarantee a minimum schedule of products and services (medical services and medicines) to all individuals, regardless of their income level (T-760/2008).

The Colombian Constitutional Court has also has an important role as protector of social rights in structural cases concerning a variety of themes, such as the lack of compliance with the state's duty to link public officials to the social security system (judgments SU-559/97, T-068/98, T-535/99, and SU-090/2000), prison overcrowding (Judgment T-153/98), too little protection granted to human rights advocates (judgment T-590/98), constitutional rights of internally displaced people (judgment T-025/2004) and the right to health care (judgment T-760/2008).

In some of these structural cases, the Colombian court declared the existence of an "unconstitutional state of affairs", which means "a massive violation of human rights, which is cause buy a significant institutional blockage that must be overcome with the engagement of various state agencies".105

In other cases, in addition to the declaration of "unconstitutional state of affairs", the court delivered "orders to the legislative and the executive related to the design and performance of specific policies and programs" and "empowered itself with the competence to supervise the fulfilment of those orders in yearly public hearings".106

Colombian justices of the Constitutional Court are considered defenders and expansionists of the welfare state, especially through decisions extending the benefits of social and economic rights to previously excluded groups. ${ }^{107}$

The Brazilian Supreme Court, Supremo Tribunal Federal (Federal Supreme Court), has also dealt with structural cases. In a decision on the violation of the constitutional

\footnotetext{
104 BERNAL-PULIDO, Carlos. The constitutional protection of economic and social rights in Latin America. In: DIXON, Rosalind; GINSBURG, Tom (Eds.). Comparative constitutional law in Latin America. Cheltenham: Edward Elgar Publishing, 2017. p. 11.

105 BERNAL-PULIDO, Carlos. The constitutional protection of economic and social rights in Latin America. In: DIXON, Rosalind; GINSBURG, Tom (Eds.). Comparative constitutional law in Latin America. Cheltenham: Edward Elgar Publishing, 2017. p. 12.

106 BERNAL-PULIDO, Carlos. The constitutional protection of economic and social rights in Latin America. In: DIXON, Rosalind; GINSBURG, Tom (Eds.). Comparative constitutional law in Latin America. Cheltenham: Edward Elgar Publishing, 2017. p. 12-13.

107 BRINKS, Daniel.; BLASS, Abby. Rethinking Judicial Empowerment: The New Foundations of Constitutional Justice. International Journal of Constitutional Law, Oxford, v. 15, n. 2, p. 296-331, apr. 2017. p. 302.
} 
rights of the inmates due to overcrowded prisons (judgment of 27 September 2015), the Brazilian Supreme Court, like its Colombian counterpart, declared the existence of "an unconstitutional state of affairs". 108

This declaration of the existence of an "unconstitutional state of affairs" means there is "a massive violation of human rights, which is cause buy a significant institutional blockage that must be overcome with the engagement of various state agencies".109

However, from a comparative perspective, the Brazilian STF does not protect rights as effectively as the Colombian Constitutional Court. Based on Ran Hirschl's theory on the "juristocracy", 110 we may construct explanations for this conclusion involving the social and political structures in Brazil and the interrelations between political and economic actors. According to Hirschl, "no theory of judicial review (...) is complete if it does not consider the political determinants of judicial empowerment and behavior, and the interplay between the political and judicial spheres".111

To make this analysis even more challenging and more complete, there are some studies that demonstrated that the poorest members of societies face greater difficulty in having their rights protected by their main courts. One study on Brazil "notes that most judicial decisions enforcing social welfare rights involve the direct provision of goods towards litigants who can afford the court system, instead of broad distributional change for the poorest". ${ }^{12}$ Even the well-regarded Constitutional Court of Colombia has had some difficulty with this matter. A study conducted by David Landau (2012) "shows (...) that judicial enforcement of social rights tends to direct resources towards higher income groups that can afford to go to court, while failing to improve the lives of the poorest citizens".113

\footnotetext{
108 BERNAL-PULIDO, Carlos. The constitutional protection of economic and social rights in Latin America. In: DIXON, Rosalind; GINSBURG, Tom (Eds.). Comparative constitutional law in Latin America. Cheltenham: Edward Elgar Publishing, 2017. p. 12.

109 BERNAL-PULIDO, Carlos. The constitutional protection of economic and social rights in Latin America. In: DIXON, Rosalind; GINSBURG, Tom (Eds.). Comparative constitutional law in Latin America. Cheltenham: Edward Elgar Publishing, 2017. p. 12.

110 HIRSCHL, Ran. 'Juristocracy' - Political, not Juridical. The Good Society, State College, vol. 13, n. 3, p. 6-11, nov. 2004; HIRSCHL, Ran. Towards Juristocracy: the origins and consequences of the new constitutionalism. Cambridge: Harvard University Press, 2007.

111 HIRSCHL, Ran. The Judicialization of Mega-Politics and the Rise of Political Courts, Annual Review of Political Science, Palo Alto, v.11, p. 93.118, 2008. p. 113.

112 CLINTON, Adam; VERSTEEG, Mila. Rights without resources: the impact of constitutional social rights on social spending. Law and Economics Research Paper Series, Charlottesville, out. 2016. Disponível em: <http:// ssrn.com/abstract=2857731>. Acesso em 30 ago. 2018. p. 8.

113 CLINTON, Adam; VERSTEEG, Mila. Rights without resources: the impact of constitutional social rights on social spending. Law and Economics Research Paper Series, Charlottesville, out. 2016. Disponível em: <http:// ssrn.com/abstract=2857731 >. Acesso em 30 ago. 2018 . p. 8.
} 


\section{CONCLUSION}

Although there are many factors that influence the role of a court with regard to the protection of rights (such as ex ante and ex post autonomy), one of the main aspects is the criterion of authority and, specifically, its second dimension (openness to access the court).

Based on the research of the scholars of the University of Brasilia Law School,114 Justice Luiz Roberto Barroso of the Brazilian Supreme Court, in a very recent decision, verified the "restrictiveness" of the Brazilian abstract judicial review system before the STF and interpreted the law to enlarge the criterion of "thematic relevance" ("pertinência temática", in Portuguese) to grant access (standing) to a national gay association to defend its ideas in an abstract constitutional review procedure (ADPF n. 527). ${ }^{115}$

The express declaration of one of the justices of the STF regarding the restrictive aspect of the Brazilian constitutional review system shows that it is one of the points that need to be considered to improve the system. A more open system that controls the number and subjects of cases that reach the court and that focuses on effective social and individual rights protection can change Brazil's "eschewed role"116 in rights adjudication.

After examining the data on the Colombian Constitutional Court's case law, Rodríguez-Raga concluded that the court plays its "vital role for the protection of citizen rights, especially because of the openness of the country's constitutional justice system". In Colombia, "not only can any citizen present in front of a lower court but also, with very few formalities, any citizen can file a constitutional challenge to legislation (i.e., an abstract review case)".117

The comparison between Brazil and Colombia presents relevant insights into how the dimension of authority and, specifically, standing to access the main courts in each system can make a large difference in the protection of social and individual rights.

\footnotetext{
114 COSTA, Alexandre Araújo; BENVINDO, Juliano Zaiden. A quem interessa o controle concentrado de constitucionalidade? O descompasso entre teoria e prática na defesa de direitos fundamentais. 2013. Disponível em: <https://papers.ssrn.com/sol3/papers.cfm?abstract_id=2509541>. Acesso em 14 ago. 2018.

115 BRAZIL. Supreme Federal Court. ADPF 527 MC. Min. Roberto Barroso. Decision of July 2, 2018, published in August 31, 2018. Available at:: <http://portal.stf.jus.br/processos/downloadPeca.asp?id=314765393\&ext=. pdf $>$. Last accessed: 30 aug. 2018.

116 HELMKE, Gretchen; RIOS-FIGUEROA, Julio. Courts in Latin America. Cambridge: Cambridge University Press, 2011. p. 23.

117 RODRIGUEZ-RAGA, Juan Carlos. Strategic Deference in the Colombian Constitutional Court, 1992-2006. In: HELMKE, Gretchen; RIOS-FIGUEROA, Julio. Courts in Latin America. Cambridge: Cambridge University Press, 2011. p. 96.
} 


\section{REFERENCES}

ALVES, José Carlos Moreira. Poder judiciário. Revista dos Tribunais, São Paulo, ano 5, n. 18, p. 269, jan./mar. 1997.

BARROSO, Luíz Roberto. O controle de constitucionalidade no direito brasileiro. 4. ed. São PauIo: Saraiva, 2011.

BENVINDO, Juliano Zaiden. A 'última palavra', o poder e a história: O Supremo Tribunal Federal e o discurso de supremacia no constitucionalismo brasileiro. Revista de informação legislativa, Brasília, v. 51, n. 201, p. 71-95, jan./mar. 2014.

BENVINDO, Juliano Zaiden. Do solipsismo supremo à deliberação racional. Direito, Estado e Sociedade, Rio de Janeiro, n. 50, p. 149-178, jan./jun. 2017.

BERNAL-PULIDO, Carlos. The constitutional protection of economic and social rights in Latin America. In: DIXON, Rosalind; GINSBURG, Tom (Eds.). Comparative constitutional law in Latin America. Cheltenham: Edward Elgar Publishing, 2017.

BRAZIL. Supreme Federal Court. ADPF 527 MC. Min. Roberto Barroso. Decision of July 2, 2018, published in August 31, 2018. Available at:: <http://portal.stf.jus.br/processos/downloadPeca.asp?id=314765393\&ext=.pdf>. Last accessed: 30 aug. 2018.

BRAZIL. Supreme Federal Court. Available at: <http://www.stf.jus.br/portal/cms/verTexto.asp?servico=estatistica\&pagina=decisoesinicio $>$. Last accessed: 30 aug. 2018.

BREWER-CÁRIAS, Allan-Randolph. Reflexiones sobre el constitucionalismo en América. Caracas: Jurídica Venezoelana, 2001.

BRINKS, Daniel. "Faithful Servants of the Regime". The Brazilian Constitutional Court's Role under 1988 Constitution. In: HELMKE, Gretchen; RIOS-FIGUEROA, Julio. Courts in Latin America. Cambridge: Cambridge University Press, 2011.

BRINKS, Daniel; BLASS, Abby. Rethinking Judicial Empowerment: The New Foundations of Constitutional Justice. International Journal of Constitutional Law, Oxford, v. 15, n. 2, p. 296-331, apr. 2017.

CANOTILHO, José Joaquim Gomes. Direito constitucional e teoria da Constituição. 7 ed. Lisboa: Almedina, 2003.

CAPPELLETTI, Mauro. $\mathbf{O}$ controle judicial de constitucionalidade das leis no direito comparado. Tradução de Aroldo Plínio Gonçalves. 2. ed. reimpressão. Porto Alegre: Sergio Antonio Fabris, 1999.

CLINTON, Adam; VERSTEEG, Mila. Rights without resources: the impact of constitutional social rights on social spending. Law and Economics Research Paper Series, Charlottesville, out. 2016. Disponível em: <http://ssrn.com/abstract=2857731 >. Acesso em 30 ago. 2018. 
COLOMBIA. Colombian Constitutional Court, Judgement T-233, 04/20/17. Available at: <https:// www.ambitojuridico.com/noticias/general/constitucional-y-derechos-humanos/aunque-fallos-de-revision-de-tutela-tengan>. Last accessed: 15 aug. 2018.

COLOMBIA. Colombian Constitutional Court. Available at: <http://www.corteconstitucional.gov. co/relatoria/estadisticas.php >. Last accessed: 30 aug. 2018

COSTA, Alexandre Araújo; BENVINDO, Juliano Zaiden. A quem interessa o controle concentrado de constitucionalidade? O descompasso entre teoria e prática na defesa de direitos fundamentais. 2013. Disponível em: <https://papers.ssrn.com/sol3/papers.cfm?abstract_id=2509541>. Acesso em 14 ago. 2018.

ERMACORA, Felix. Österreichs Bundesverfassung und Hans Kelsen. In: MERKL, Adolf; VERDROß, Alfred; MARCIC, René; WALTER, Robert (Eds.). Festschrift Für Hans Kelsen Zum 90. Geburtstage. Wien: Verlag Franz Deuticke, 1971.

FAVOREU, Louis. Constitutional courts. Baton Rouge: Center of Civil Law Studies - LSU Law Center, 2001. Disponível em: <http://books.google.com.br/books?id=CVxQAQAAIAAJ\&q=louis+favoreu+2001\&dq=louis +favoreu+2001\&hl=en\&sa=X\&ei=tUnlU9OVBo7ksATql4CoBQ\&ved=0CBsQ6AEwAA>. Acesso em: 3 abr. 2014.

GINSBURG, Tom; VERSTEEG, Mila. Why do countries adopt constitutional review? Journal of Law, Economics and Organization, Oxford, v. 30, n. 3, p. 587, 2014.

HECKMANN, Dirk. Geltungskraft und Geltungsverlust von Rechtsnormen. Tübingen: Mohr Siebeck, 1997.

HELMKE, Gretchen; RIOS-FIGUEROA, Julio. Courts in Latin America. Cambridge: Cambridge University Press, 2011.

HEUN, Werner. Normenkontrolle. In: BAND, Erster. Festschrift 50 Jahre Bundesverfassungsgerich. Herausgegeben von Peter Badura und Horst Dreier: Verfassungsgerichtsbarkeit, Verfassungsprozeß. Tübigen: Mohr Siebeck, 2001.

HIRSCHL, Ran. 'Juristocracy' - Political, not Juridical. The Good Society, State College, vol. 13, n. 3, p. 6-11, nov. 2004.

HIRSCHL, Ran. The Judicialization of Mega-Politics and the Rise of Political Courts, Annual Review of Political Science, Palo Alto, v.11, p. 93.118, 2008.

HIRSCHL, Ran. Towards Juristocracy: the origins and consequences of the new constitutionalism. Cambridge: Harvard University Press, 2007.

IPSEN, Jörn. Rechtsfolgen der Verfassungswidrigkeit von Norm und Einzelakt. Baden-Baden: Nomos Verlagsgesellschaft, 1980.

JACKSON, Vicki C.; TUSHNET, Mark. Comparative constitutional law. 2. ed. New York: Foundation Press, 2006. 
KAPISZEWSKI, Diana. Power Broker, Policy Maker, or Rights Protector:The Brazilian Supremo Tribunal Federal in Transition. In: HELMKE, Gretchen; RIOS-FIGUEROA, Julio. Courts in Latin America. Cambridge: Cambridge University Press, 2011.

KELSEN, Hans. Jurisdição constitucional. São Paulo: Martins Fontes, 2007.

MENDES, Gilmar Ferreira. Estado de direito e jurisdição constitucional 2002-2010. São Paulo: Saraiva, 2011.

NOWAK, John. E.; ROTUNDA, Ronald D. Constitutional law. 4. ed. St. Paul: West Publishing Co., 1991, p. 1-20; 22-114.

PIEROTH, Bodo; SCHLINK, Bernhard. Direitos fundamentais. Tradução de António Francisco de Sousa e António Franco. São Paulo: Saraiva, 2012.

REHNQUIST, William. H. The Supreme Court. New York: Vintage Books, 2002.

RÍOS-FIGUEROA, Julio. Institutions for Constitutional Justice in Latin America. In: HELMKE, Gretchen; RIOS-FIGUEROA, Julio. Courts in Latin America. Cambridge: Cambridge University Press, 2011.

RODRIGUEZ-RAGA, Juan Carlos. Strategic Deference in the Colombian Constitutional Court, 19922006. In: HELMKE, Gretchen; RIOS-FIGUEROA, Julio. Courts in Latin America. Cambridge: Cambridge University Press, 2011.

ROSENBERG, Gerald. The Hollow Hope: Can Courts bring about social change? Chicago: University of Chicago Press. 1991.

SCHOR, Miguel. Constitutionalism Through the Looking Glass of Latin America. Texas International Law Journal, Austin, v. 41, n. 1, p. 1-35, 2005.

SEGADO, Francisco Fernandez. La obsolescencia de la bipolaridade tradicional (modelo Americano - modelo europeo-kelseniano) de los sistemas de justicia constitucional. Direito Público, Brasília, ano 1, n. 2, p. 55-82, out./dez. 2003.

SNOWISS, Sylvia. Judicial review and the law of the Constitution. New Haven: Yale University Press, 1990.

STATON, Jeffrey; MOORE, Will. Judicial Power in Domestic and International Politics, International Organization, Cambridge, v. 65, n. 3, 2011, p. 553-587.

SWEET, Alec Stone. Governing with judges: Constitutional Politics in Europe. New York: Oxford University Press, 2000.

SWEET, Alec Stone; SHAPIRO, Martin. Abstract and concrete review in the United States. In: SWEET, Alec Stone; SHAPIRO, Martin. On Law, politics, and judicialization. Oxford: Oxford Scholarship Online. 2006. 
TOCQUEVILLE, Alexis de. Democracy in America. Tradução de R. D. Heffner. New York: New American Library, 2001.

TREANOR, William. Judicial Review before Marbury. Stanford Law Review, Stanford, v. 58, n. 2, p. 455-562, 2005.

TRIBE, Laurence H. American constitutional law. 3. ed. New York: Foundation Press, v. 1, p. 207$285 ; 302-385,2000$.

UNITED STATES. United States Supreme Court. Marbury v. Madison. Justia.com: US Supreme Court Center. 19 p. Disponível em: <http://supreme.justia.com/cases/federal/us/5/137/case. html>. Acesso em: 18 set. 2013. 